\title{
Teaching with Multimedia Technique in International Business Negotiation*
}

\author{
Wang Ru \\ School of Foreign Languages and Cultures, Beijing Wuzi University, Beijing, 101149, China \\ wangru@bwu.edu.cn
}

\begin{abstract}
Business terms and international business negotiation theories, as is known to everyone, are unintelligible, abstract, and unacceptable to many college students and other learners. This paper aims to analyze the modern teaching means, multimedia-assisted teaching, which can serve their needs with maps, text, sound in the classroom, creating a virtual business environment as well as interactive teaching networking system, which assists the students' comprehension of business expertise, and enhances their skills of fulfilling a successful international business negotiation. Certainly, it can also make up for the deficiencies of the traditional teaching practice.

Index Terms - Multimedia, Business Negotiation, Audio-visual
\end{abstract}

\section{Introduction}

With the opening of China's market to the outside world, foreign economic exchanges has been increasing obviously. Business English has, therefore, drawn more and more attention of both educators and students and undoubtedly aroused their additional interest. Based on the analysis of the teaching practice of business negotiation, the writer summarizes distinctive features of multimedia and discusses some relevant problems and proposals.

Business English, as ESP( English for Special Purposes), is substantial part of Chinese college education. And International Business Negotiation is one of business English courses which is rather practical and of great importance for students' future career[10].

The students majoring in Business English should be educated to be professional elitists. They should have solid foundation in English and enough business background, capable of accomplishing interpreting, assisting and managing works. However, monotonous traditional teaching mode always fails to create a particular business environment and specific business case situation, which actually has neglected this initial teaching objective and lowered actual teaching effectiveness.

Business English audio-visual teaching is to integrate all business knowledge of different relevant areas into practical business transactions in class by full use of modern media. It is a kind of information technology that combines the text with graphics, video, animation and voice, handled and controlled by computer software[9]. With the development of the educational business and reform in college education system, as an entirely new teaching assistant tool, multimedia has become a vital part of the classroom teaching(see Fig.1).

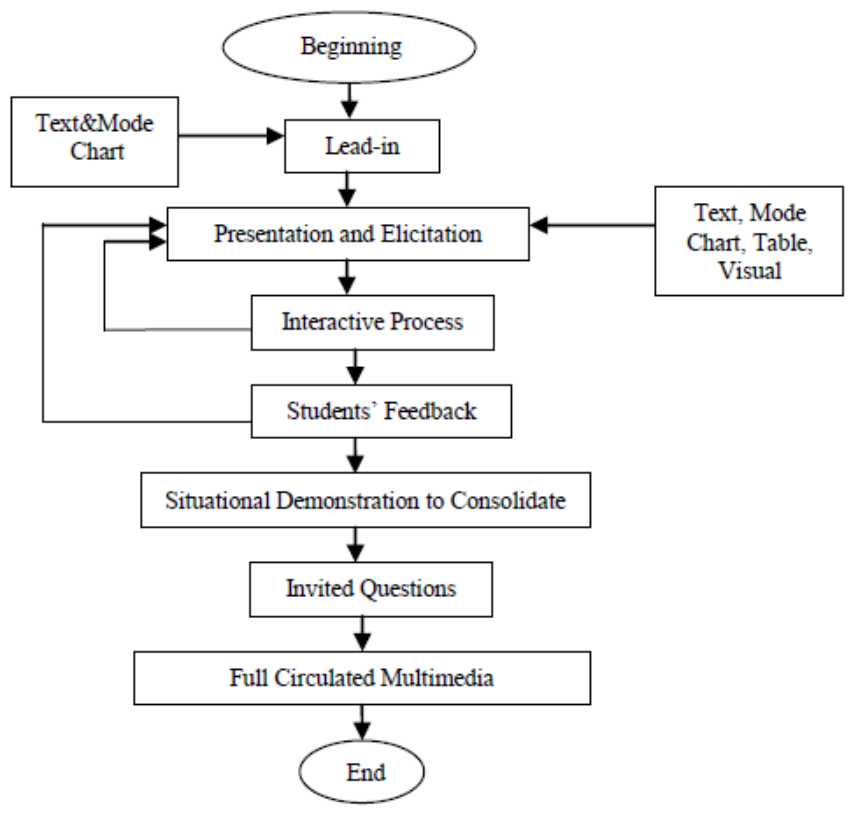

Fig. 1 Application of Multimedia in Classroom Teaching

In the past several decades until 90 s of last century, the classroom teaching was always based on blackboard, chalk, mouth and book, i.e., traditional teaching type. The traditional type teaching required the students to be good at imagination and super dedicated when study, since almost all of the knowledge could only be introduced in the forms of text. As a result, the effectiveness of traditional teaching was all along under questions especially when novel teaching type based on multimedia technology appeared. The novel type was called multimedia teaching. In the past decade, multimedia teaching had a mushroom growth thanks to the popularization of personal computer. It had been proved useful in enhancing the interests of students in studying and therefore improving the effectiveness of obtaining knowledge[2-3, 5-6].

Applying the multimedia in teaching can simplify business courses, emphasize focal points and difficulties, and present the main idea to students vividly and clearly. To be more specific, audio-visual materials bring the real business situation to the class, help students use the authentic business language for communication and become better aware of

\footnotetext{
* This research paper is imbursed by PHR(IHLB).
} 
product development, sales promotion, customer service, staff recruitment, business law, distribution channels and so on. Moreover, multimedia can reduce the burden of students, excite their interest and enthusiasm, help them learn how to think, analyze and make judgment.

\section{Application of multimedia in international business negotiation teaching}

Experimental Psychologist Red Rui Tela( Treichter) has conducted experiments on human beings' memories. The results shows that people usually remember $10 \%$ of what they read, $20 \%$ of what they hear, $30 \%$ of what they see, $50 \%$ of what they communicate and exchange with others, and $70 \%$ of what they said. Hence, students' organic functions of watching, hearing and speaking should all be used in learning within limited time in class efficiently. Multimedia allows teachers to make full use of a diversity of teaching methods, such as audio-visual film, video, and Internet. This is to take international business negotiation, the typical business course, as example in the following:

\section{A. Analyzing Teaching Material and Selecting Right Method to Present}

When starting this new course for the students, teachers must see that they are fully attracted right in the first lecture and make sure to build their confidence. For example, Chapter One-Fundamental Theories of Business Negotiation \& Communication, published by Higher Education Press-is employed here to explain how to analyze and what to select in business negotiation teaching[4].

The first chapter is surely basis for latter study. In this chapter, major negotiation key terminologies and some basic concepts of business negotiation such as types, characteristics, elements are all included in the list of illustration. Among them, the most difficult part lies in the terminologies, i.e. counterpart, stake and conflict (see Fig.2).

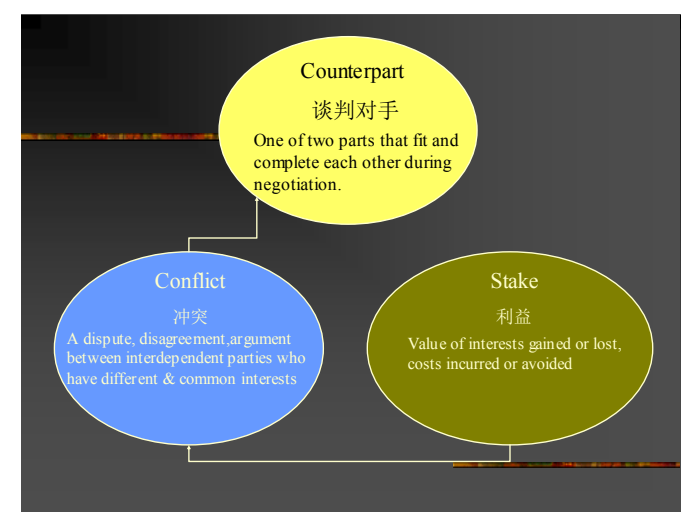

Fig. 2 Three Basic Terminologies in International Business Negotiation

Besides, it's not easy job to finish all explanation within just 2 hours. Therefore, it is advisable to arrange 1 hour to upfold before the students' eyes a common negotiation circumstance with multimedia. These obscure terms would be easily understood under this actual situation. Of course, multimedia may also be of great help when demonstrating all concerning theories in order for better efficiency.

\section{B. Designing Appropriate Multimedia as Teaching Aid}

As per the above analysis, the writer shows a cartoon named Family Asset Allocation[1]:

a. Characters:

Mr. Zhang: a teacher of a middle school

His wife Linda: a teacher of a primary school

Son Steward: a university graduate, applying for the entrance into a foreign university for post-graduate study

Daughter Lily: a student in a local famous middle school who is a lover of piano

b. Stake: 120,000 Yuan of deposit

c. Conflict:

Zhang plans to buy a car for traveling

His wife Linda wants to buy a new flat for the family

Son Steward demands financial support for studying abroad

Daughter Lily loves a piano both for leisure time and for special training

After enjoying this dramatic cartoon which is quite close to our daily life, students feel not anxious about business learning any longer and get to know what is stake and conflict all about. Right afterwards, a well-prepared PPT functions in introducing types, characteristics, elements of business negotiation. Simply with several pages, these theories can be easily conveyed to the students. No doubt, traditional teaching method needs more extra time to do the same.

Finally, to consolidate all that have been learnt, a simulation exercise is always necessary end of the lecture. Two students are arranged into a team to simulate a case named Shopping in Manhattan[1]:

a. Characters

Shop assistant: sold an expensive video camera to Miss Li who is a Chinese student studying in New York University, once looking for a video camera in Manhattan

Mr. Wang: Leader of Chinese Section of New York Consumer's Association

b. Event

Miss Li paid \$300 more for a camera, while the shop assistant said that the camera was non-refundable. She asked for help from New York Consumer's Association. Mr. Wang dialed and warned the shop assistant. He asked him if he let the customer into a separate room, induced her into accepting what she did not want and sent for a man following her to the bank for money. Mr. Wang declared that all these behaviors were illegal. Besides, Mr. Wang warned him that there would be appeal against him if he did not value the golden shopping time before Christmas.

Since it's the first warm-up simulation exercise, two involved negotiation parties may find it much easier to perform a general negotiation like this. They are familiar with such shopping event, which can even be shown as background with computer, including dynamic shopping video and audio effect of shopping noise. Meanwhile, some recommended reference sentences are placed on the screen. Students are just 
intoxicated and able to get into the situation without any difficulties.

Generally speaking, there's some after-class homework to do online, reflecting how well the students have studied, by which teacher and students may interact with each other.

\section{The Conditions of Multimedia Teaching Applications in Business English Teaching}

Generally speaking, the major means used in multimedia teaching was something called as courseware. Courseware referred to the targeted computer software designed for teaching activities. It often assembled text, figure, chart, sound and animation at the same time. The common courseware used in China was powerpoint released by Microsoft corporation. In this part, the conditions of multimedia teaching applications were surveyed by the means of surveying the applications of courseware in classroom. As referred before, courseware was the core of multimedia teaching, and the investigation of courseware could offer essential information of multimedia teaching. A random investigation to 20 teachers of a normal university in Anhui province, China was carried out and the results were sorted out in Table 1.

\begin{tabular}{|c|c|c|c|c|c|c|c|c|c|c|}
\hline No. & 1 & 2 & 3 & 4 & 5 & 6 & 7 & 8 & 9 & 10 \\
\hline Gender & $\mathrm{M}^{2}$ & $\mathrm{~F}^{h}$ & $\mathrm{~F}$ & F & $\mathrm{M}$ & M & M & $\mathrm{F}$ & M & \\
\hline & $40 \sim 50$ & $30 \sim 40$ & $40 \sim 50$ & $40 \sim 50$ & $30 \sim 40$ & $40 \sim 50$ & $30 \sim 40$ & $30 \sim 40$ & $40 \sim 50$ & $40 \sim 50$ \\
\hline PPT Used & $Y^{6}$ & Y & Y & $\mathrm{N}^{\mathrm{d}}$ & Y & Y & Y & Y & Y & $\mathrm{N}$ \\
\hline $\begin{array}{l}\text { Course } \\
\text { No. }\end{array}$ & 11 & 12 & 13 & 14 & 15 & 16 & 17 & 18 & 19 & 20 \\
\hline Gender & $\mathrm{F}$ & $\mathrm{M}$ & M & M & F & $\mathrm{F}$ & M & & F & \\
\hline & $40 \sim 50$ & $40 \sim 50$ & $40 \sim 50$ & $40 \sim 50$ & $30 \sim 40$ & $30 \sim 40$ & $30 \sim 40$ & $30 \sim 40$ & $30 \sim 40$ & $30 \sim 40$ \\
\hline PPT Used & $\mathrm{N}$ & $\mathrm{N}$ & $\mathrm{N}$ & $\mathrm{N}$ & $\mathrm{N}$ & Y & Y & $\mathrm{N}$ & $\mathrm{N}$ & Y \\
\hline
\end{tabular}

To avoid the difference caused by gender, age of teacher, or course nature, ten female and ten male teachers, ten of whose age were among 30 40 and the other among 40 50, were chosen. Besides, ten natural science courses, course no. $1 \sim 10$, and ten social science course, course no. 11 20 were chosen. The classification results of table 1 were shown in Table 2.

Table 2. The Classification Results of Multimedia Teaching Applications

\begin{tabular}{clcl}
\hline Classification & & No. of PPT Used & Proportion (\%) \\
\hline \multicolumn{1}{c}{ Gender } & Male & 7 & 70 \\
& Female & 4 & 40 \\
\hline Course & Natural & 8 & 80 \\
Nature & & & \\
& Social & 3 & 30 \\
\hline Age & $30 \sim 40$ & 7 & 70 \\
& $40 \sim 50$ & 4 & 40 \\
\hline Total & & 11 & 55 \\
\hline
\end{tabular}

Table 2 shows that multimedia teaching applications were greatly connected with gender, age of teacher and course nature. It was natural that young or male people were more familiar with and more interested in computer applications and more inclined to adopt multimedia technology in teaching activities than elder or female ones. On the other hand, natural science course usually paid close attention to natural process such as chemical reactions, physical movements and etc., which were relatively easier to be represented by multimedia, rather than social science course. To be more specific, business English, as a professional course in which many business situations need to be presented as either background or other uses, multimedia may really help a lot[7].

\section{Problems and suggestions in teaching business negotiation with multimedia}

Obviously, the impersonal effects of multimedia teaching could not be ignored. However, the effects of multimedia teaching on students' learning were still mooted among researchers. Considerable studies had proved the multimedia teaching abortive to impart knowledge to students compared with traditional teaching, although it seemed much more reverse conclusions reported [8].

\section{A. Restrict the Relationship between Teacher and Students}

Classroom teaching is an activity that involves both teacher and students. The teacher can judge whether the students understand or feel unsure by communicating with them, adjust his/her teaching process and teaching method flexibly. While in the teaching with multimedia, it is so powerful that the background and voiced language can be realized with visual and audio help, which very often replaces the communicational drills and thinking training. If the teacher doesn ' t pay attention to the communication with the students and only operate the mouse in front of the computer, the teacher and the students will face to the computer and the display screen respectively, which must block the affective communication between the teacher and the students. Then, teaching atmosphere is depressed, the leading role of teacher and the main position of the students can not be exemplified, the enthusiasm of students can not be motivated neither.

It's universally admitted that although multimedia has a number of incomparable merits, the teacher should play the leading role after all and the interaction between the teacher and the students is the most efficient teaching and learning channel.

\section{B. Redundantly use and rely on the multimedia}

Some teachers use the multimedia in the whole teaching process, busy with switching the screen. The teaching process becomes the operation of the computer and the students are watching and listening to the courseware all through the class. Students turn out to be spectators rather than centre of the class. In fact, multimedia offers a lot more information; but distracts the attention from the students at the same time, which prohibits many students from following the teacher.

Teachers should be clear that they use multimedia in order to pick the language points, activate the teaching material and create the real language situation. Guidance and explanation from the teacher is eventually core of any business classes. Teaching efficiency would not be perfect only if combining multimedia with other teaching means. Other 
instructional media and means also have special functions that can not be replaced by multimedia, such as the object and simple drawing. For instance, when explaining how we use fax machine to send important document as part of negotiation preparation, it's much better to let students feel the machine and even operate it themselves, because the brain accepts the object first and then the picture.So the teacher should choose the appropriate media and means, exerting their own advantages in serving the class.

\section{Conclusion}

Teaching with multimedia is a kind of modernized teaching means and an entirely new teaching mode. As for the traditional teaching, multimedia is a fangle, so there will be various problems when using them. Therefore, we should make good use of audio-visual multimedia as a functional teaching method, exploit a new teaching model, optimize teaching process and increase business English teaching quality.

\section{Acknowledgment}

I would like to take this opportunity to thank $\mathrm{Mr}$. Wu Shangyi who offers me academic and constructive advice on composing this paper. His encouragement and help are worthy of high acknowledgement. Without his help I could not finish this paper. He helps me to amend this paper, and gives me not only advice on the content of the paper but also the attitude of writing this paper.

\section{References}

[1] Baiyuan, International Business Negotiation Theory Cases and Practices, Beijing: China Renmin University Press, 2003.

[2] Cook, M.P., "Visual Representations in Science Education: The Influence of Prior Knowledge and Cognitive Load Theory on Instructional Design Principles," Science Education, vol. 90, No. 6, pp. 1073-1091, 2006.

[3] Homeyra R.S, "Controlled Study on the Effectiveness of Multimedia Learning Modules for Teaching Mechanics," Physical Review Special Topics- Physics Education Research, vol. 8, No. 1, pp. 97-10.

[4] Jiang Lei, English for International Business Negotiation and Communication, Beijing: Higher Education Press, 2009.

[5] Johnson A., Moher T., Ohlsson S., Leigh J, "Exploring Multiple Representations in Elementary School Science Education," 2001 Proceedings on IEEE Virtual Reality, pp. 201-208, 2001.

[6] Kuo-Chuan Yeh, Ying Xie, Fengfeng Ke, "Teaching Computational Thinking to non-Computing Majors using Spreadsheet Functions," 2011 Frontiers in Education Conference, pp. F3J-1-F3J-5, 2011.

[7] Li Ruiji, "Investigation and Study on Students' Degree of Satisfaction of Multimedia Teaching," JCIT: Journal of Convergence Information Technology, Vol.7, No.11, pp. 262- 270, 2012.

[8] Tang T. L. P., Austin M. J., "Students' Perceptions of Teaching Technologies, Application of Technologies and Academic Performance," Computer \& Education, vol. 53, No. 1, pp. 1241-1255, 2009.

[9] Tang Yanyu, Modern Education Technology and Multimedia English Teaching, Suzhou: Suzhou University Press, 2011.

[10] http://en.wikipedia.org 